\title{
Changes in soil carbon sequestration and emission in different succession stages of biological soil crusts in a sand-binding area
}

Bo Wang ${ }^{1,2}$, Jing Liu ${ }^{1 *}$, Xin Zhang ${ }^{3}$ and Chenglong Wang ${ }^{1}$

\begin{abstract}
Background: We investigated the spatio-temporal dynamics of soil carbon dioxide $\left(\mathrm{CO}_{2}\right)$ - and soil methane $\left(\mathrm{CH}_{4}\right)$-flux during biological soil crust (BSCs) deposition in a sand-binding area in the eastern Chinese Hobq Desert. The trends in soil organic carbon (C) content and density were analyzed during this process. The sampling sites comprised a mobile dune (control) and those with algal, lichen, and moss crust-fixed sands. The desert soil $\mathrm{CO}_{2}$ - and $\mathrm{CH}_{4}$-flux, temperature, and water content were measured from May to October in 2017 and 2018. Simultaneously, organic $C$ content and density were measured and analyzed by stratification.

Results: The spatio-temporal variation in desert soil $\mathrm{CO}_{2}$-flux was apparent. The average $\mathrm{CO}_{2}$-fluxes in the control, algal, lichen, and moss sites were $1.67,2.61,5.83$, and $6.84 \mathrm{mmol} \mathrm{m}^{-2} \mathrm{~h}^{-1}$, respectively, during the growing season, and the average $\mathrm{CH}_{4}$-fluxes in the four sites were $-1.13,-1.67,-3.66$, and $-3.77 \mu \mathrm{mol} \mathrm{m}{ }^{-2} \mathrm{~h}^{-1}$, respectively. Soil temperature was significantly positively correlated with $\mathrm{CO}_{2}$-flux but could not influence $\mathrm{CH}_{4}$ absorption, and $\mathrm{C}$ flux had minimal correlation with soil water content. The soil total organic $\mathrm{C}$ density at all sites was significantly different and decreased as follows: moss > lichen > algal > control; moreover, it decreased with soil depth at all sites. The accumulation of desert soil organic $C$ could enhance soil $C$ emissions.

Conclusion: In a semi-arid desert, artificial planting could promote sand fixation and BSCs succession; therefore, increasing the $\mathrm{C}$ storage capacity of desert soils and decreasing soil $\mathrm{C}$ emissions could alter the $\mathrm{C}$ cycle pattern in desert ecosystems. Soil temperature is the major factor controlling desert soil $\mathrm{CO}_{2}$ flux and vegetation restoration, and BSCs development could alter the response patterns of $C$ emissions to moisture conditions in desert soils. The results provide a scientific basis for studying the $C$ cycle in desert ecosystems.
\end{abstract}

Keywords: Hobq Desert, Carbon emission, Soil carbon density, Biological soil crusts, Hydrothermal factors

\section{Background}

Ecosystem carbon (C) stocks result from long-term C accumulation and comprise plant, litter, and soil C stocks. Their amounts can vary depending on ecosystem type, regional environmental conditions, and anthropogenic interventions, which are the theoretical basis for the

*Correspondence: ljing58@126.com

${ }^{1}$ College of Desert Control Science and Engineering, Inner Mongolia Agricultural University, Hohhot 010018, China

Full list of author information is available at the end of the article enhancement of ecosystem $C$ stocks through land-use/ cover change. Soils are the largest $\mathrm{C}$ pools in terrestrial ecosystems, with a reservoir size approximately twice that of atmospheric $\mathrm{C}$ pools and thrice that of vegetation $\mathrm{C}$ pools [1]. Soil $\mathrm{C}$ content and density directly affect the net primary productivity of plants and are important indicators of soil fertility. The variation in ecosystem $\mathrm{CO}_{2}$ and $\mathrm{CH}_{4}$ emissions significantly affects $\mathrm{C}$ pools and is a direct or indirect contributor to global warming. Therefore, scientific questions about the stability of $\mathrm{C}$ pools and their distribution among different compartments, as 
well as the biogeochemical cycling of $\mathrm{CO}_{2}$ and $\mathrm{CH}_{4}$, have been at the heart of climate change research.

Soil $\mathrm{C}$ flux refers to the $\mathrm{CO}_{2}$ and $\mathrm{CH}_{4}$ flux at the soil surface, which is the main source of $\mathrm{C}$ emissions from the soil to the atmosphere [2]. In contrast, soil organic $\mathrm{C}$ (SOC) indicates the balance between the input of organic matter, such as biological residues, into the soil and its loss from the soil, mainly due to soil microorganism decomposition and soil respiration, which is an indicator for the direct measurement and evaluation of soil $\mathrm{C}$ storage capacity [3]. Therefore, small changes in soil $\mathrm{C}$ flux and organic $\mathrm{C}$ content, which are the important components of the pathway between the input and output of soil $\mathrm{C}$ pools, directly alter the $\mathrm{C}$ stocks in the pedosphere and atmosphere, thereby affecting ecosystem $\mathrm{C}$ cycling processes and global $\mathrm{C}$ balance [4]. The study of soil $\mathrm{C}$ fluxes and stocks in terrestrial ecosystems, especially the exploration of changes in soil $\mathrm{C}$ pools under different land-use patterns in the context of global climate change, can provide scientific basis for ecological management, such as plantation forest construction, natural forest protection, returning farmland to forests and grasslands, and desertification control, thereby clarifying its value and ensuring its rationality.

At present, extensive research has been conducted on soil C dynamics in natural ecosystems (e.g., forests, grasslands, and wetlands) and artificial ecosystems (e.g., urban green spaces and farmlands), mainly focusing on soil respiration rate, ecological stoichiometric characteristics, $\mathrm{C}$ and nitrogen distribution patterns, and $\mathrm{C}$ mineralization and turnover characteristics [5-8]. As an important component of terrestrial ecosystems, desert ecosystems are characterized by homogeneous vegetation, low coverage, and severe erosion. Desert soils account for approximately $9.5 \%$ of the total $\mathrm{C}$ stock in the pedosphere and play a crucial role in the global $\mathrm{C}$ cycle [9]. Therefore, it is of great significance to study the dynamic characteristics of desert soil $C$, especially soil surface $C$ flux and underground $C$ stocks, to accurately assess the $C$ budget in desert areas and to formulate scientific and rational measures for their management and utilization.

In China, extensive desertification control has been carried out on desertified lands in arid and semi-arid regions as well as on the edges of large deserts and oasis extensions. The promotion of sand fixation by artificial planting can facilitate vegetation restoration and improve regional microhabitats, thus forming stable ecosystems with the natural succession of communities [10]. In this process, as the vegetation coverage increases, the vegetation-soil feedback affects soil physicochemical properties, root distribution, microbial colonization, and soil fauna activity, while also promoting the development of biological soil crusts (BSCs) and a tendency toward mature succession [11]. Algae crust is the early developmental stage of BSCs, and an increase in algal and fungal biomass is a prerequisite for the formation of lichen and algae crusts; lichen crust continuously improves soil texture and provides a stable topsoil environment for the survival of moss. Current research on BSCs is mainly concerned with its effects on the spatial distribution of soil moisture, soil microbial community, and vegetation structure [12-14]. Additionally, BSCs have been shown to be an essential $C$ source that can change soil respiration characteristics in desert ecosystems [15]. However, there is still a lack of systematic studies on the changes in soil C fluxes and stocks during the succession of BSCs and their mechanisms of influence. The Hobq Desert is the seventh largest desert in China, occupying the narrow strip of land between the northern part of the Ordos Plateau and the south bank of the Yellow River. It is one of the major sand sources in northern China. In this study, we examined the soil of an artificial sand-fixing area in the eastern Hobq Desert, using BSCs development as the basis for the division of sample sites, which were as follows: mobile dunes without crusts, algal crusted sandy land in the early developmental stage, lichen crusted sandy land in the middle stage, and moss crusted sandy land in the mature stage, with the aim of clarifying: (1) the spatiotemporal dynamics of soil $\mathrm{CO}_{2}$ and $\mathrm{CH}_{4}$ flux and its environmental controlling factors, (2) the dynamic variations in SOC content and density, and (3) the synergistic relationship between $C$ flux and $C$ stock in desert soils during vegetation restoration and $\mathrm{BSCs}$ succession.

\section{Results}

\section{Variations of $\mathrm{CO}_{2}$ fluxes and hydrothermal factors in desert soil}

The climate of the study area was characterized by the clear concurrence of precipitation and high temperatures, with more rainfall and higher temperatures during the growing season. During the growing seasons of 2017 and 2018, the cumulative precipitation amounts were 220.2 and $284.4 \mathrm{~mm}$, respectively, and the average temperatures were 20.8 and $19.9^{\circ} \mathrm{C}$, respectively (Fig. 1).

There were no significant differences in soil temperature among the control, algal, lichen, and moss sample sites $(P>0.05)$, except in June. Seasonal variations showed distinct unimodal curves (Table 1), with relatively high soil temperatures in June and July, and the lowest temperature occurring in late October. Certain differences were observed in the soil water content of the four sample sites, whereby the soil water content of the control site was significantly higher than that of the algal and lichen sites and slightly higher than that of the moss site. All four sample sites showed evident seasonal variation in their soil water content, which was 

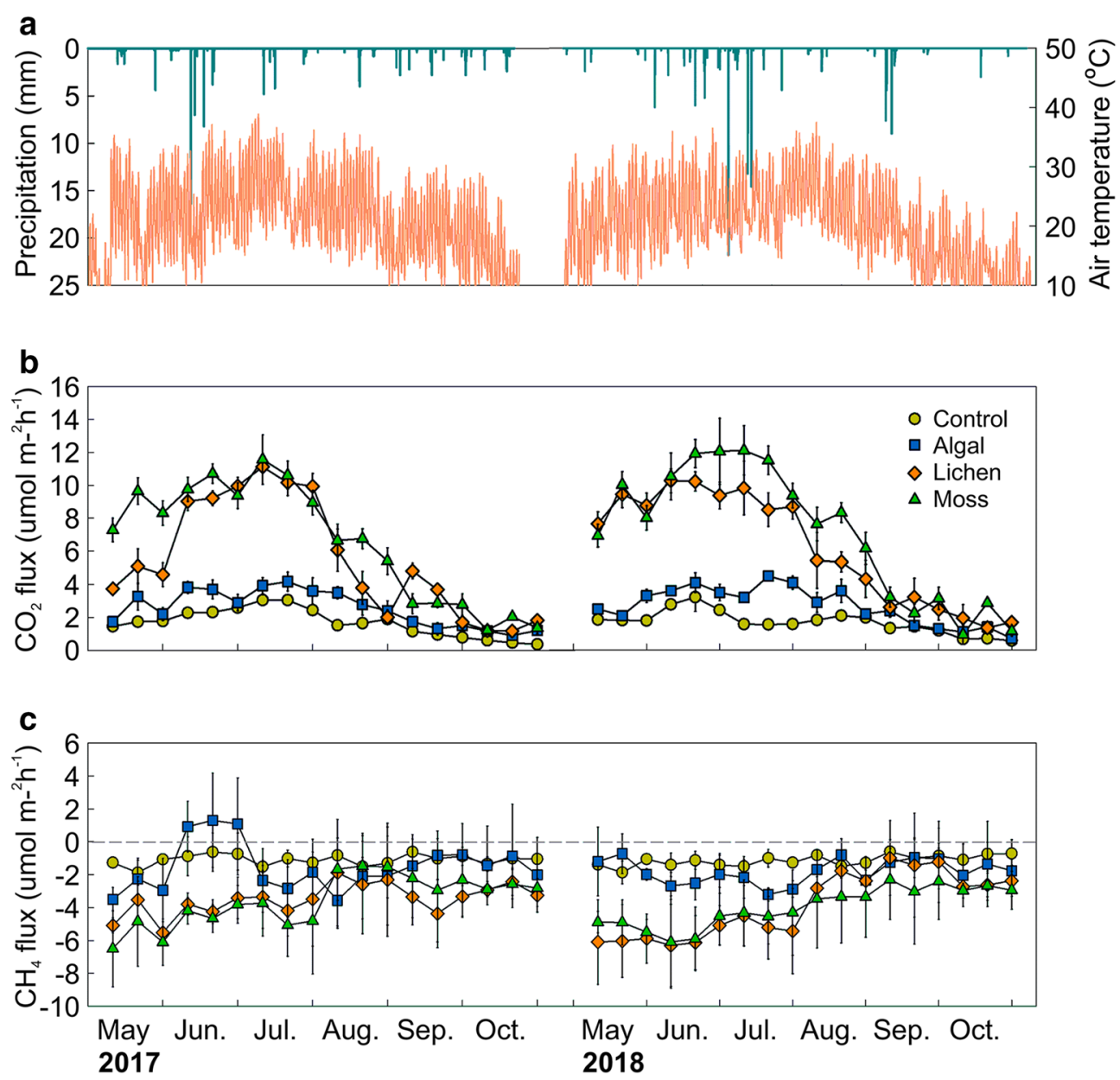

Fig. 1 Time series of soil $\mathrm{CO}_{2}$ and $\mathrm{CH}_{4}$ fluxes and climatic factors. Time series of climatic factors, and soil $\mathrm{CO}_{2}$ and $\mathrm{CH}_{4}$ fluxes at Hobq Desert (Inner Mongolia, China) in 2017 and 2018. The top panel shows precipitation and air temperature in the study area, the bottom two panels show soil $\mathrm{CO}_{2}$ and $\mathrm{CH}_{4}$ fluxes at the control, algal, lichen, and moss sites. Data are shown as means with standard errors

Table 1 Mean soil temperature and water content at different soil depths during developmental stages of BSC

\begin{tabular}{|c|c|c|c|c|c|c|c|c|}
\hline Sample plots & Item & May & June & July & August & September & October & Growing season \\
\hline Control & \multirow{4}{*}{$\begin{array}{l}\text { Soil water content } \\
(\%)\end{array}$} & $9.24 \pm 1.31^{\mathrm{Ab}}$ & $7.63 \pm 0.93^{\mathrm{Ca}}$ & $6.66 \pm 0.43^{\mathrm{Da}}$ & $7.61 \pm 0.61^{\mathrm{Ca}}$ & $9.42 \pm 1.27^{\mathrm{Aa}}$ & $8.45 \pm 0.23^{B b}$ & $8.16 \pm 0.82^{\mathrm{a}}$ \\
\hline Algal & & $8.75 \pm 0.79^{B C}$ & $6.41 \pm 0.67^{c c}$ & $4.28 \pm 1.73^{\mathrm{EC}}$ & $5.32 \pm 1.89^{\mathrm{DC}}$ & $9.83 \pm 1.03^{\mathrm{Aa}}$ & $8.18 \pm 1.83^{\mathrm{Bb}}$ & $7.22 \pm 1.34^{b}$ \\
\hline Lichen & & $9.11 \pm 1.15^{\mathrm{Abc}}$ & $7.15 \pm 0.89^{\mathrm{Bb}}$ & $5.56 \pm 1.22^{\mathrm{Cb}}$ & $5.75 \pm 1.76^{\mathrm{Cbc}}$ & $=9.39 \pm 0.94^{\mathrm{Aa}}$ & $7.85 \pm 1.69^{\mathrm{Bb}}$ & $7.58 \pm 1.28^{\mathrm{ab}}$ \\
\hline Moss & & $10.21 \pm 1.04^{\mathrm{Aa}}$ & $6.46 \pm 1.78^{B C}$ & $5.05 \pm 1.94^{\mathrm{Cbc}}$ & $6.14 \pm 2.29^{\mathrm{Bb}}$ & $9.91 \pm 1.19^{\mathrm{Aa}}$ & $9.65 \pm 2.13^{\mathrm{Aa}}$ & $7.93 \pm 1.73^{\mathrm{a}}$ \\
\hline Control & \multirow{4}{*}{$\begin{array}{l}\text { Soil temperature } \\
\left({ }^{\circ} \mathrm{C}\right)\end{array}$} & $22.51 \pm 0.35^{\mathrm{Da}}$ & $35.64 \pm 0.54^{\mathrm{Aa}}$ & $30.72 \pm 0.53^{\mathrm{Bb}}$ & $27.16 \pm 1.40^{\mathrm{Ca}}$ & $21.74 \pm 0.57^{\mathrm{Db}}$ & $14.14 \pm 0.37^{\mathrm{Ea}}$ & $25.31 \pm 0.69^{a}$ \\
\hline Algal & & $18.92 \pm 0.99^{\complement c}$ & $28.01 \pm 0.38^{\mathrm{Bd}}$ & $32.64 \pm 0.76^{\mathrm{Aa}}$ & $27.85 \pm 0.69^{\mathrm{Ba}}$ & $20.40 \pm 0.37^{\mathrm{cb}}$ & $12.72 \pm 0.22^{\mathrm{Db}}$ & $23.42 \pm 0.76^{b}$ \\
\hline Lichen & & $20.85 \pm 1.20^{\mathrm{Cb}}$ & $33.49 \pm 0.27^{A b}$ & $32.45 \pm 1.26^{\mathrm{Aa}}$ & $27.73 \pm 0.49^{\mathrm{Ba}}$ & $20.78 \pm 0.50^{\mathrm{cb}}$ & $12.82 \pm 0.42^{\mathrm{Db}}$ & $24.62 \pm 0.79^{a}$ \\
\hline Moss & & $20.47 \pm 1.03^{\mathrm{Db}}$ & $29.30 \pm 1.17^{B C}$ & $32.82 \pm 1.34^{\mathrm{Aa}}$ & $27.91 \pm 0.60^{\mathrm{Ba}}$ & $25.01 \pm 1.17^{\mathrm{Ca}}$ & $13.17 \pm 1.66^{\mathrm{Eb}}$ & $24.78 \pm 1.21^{\mathrm{a}}$ \\
\hline
\end{tabular}

The lower case letters indicate significant differences at 0.05 level among the four sites in the same month; the uppercase letters indicate significant differences at 0.05 level during the 6 months at the same site

BSCs biological soil crusts 
lower in June and July, and higher in May and October, thus exhibiting a dynamic pattern that was opposite to that of soil temperature.

During the growing season, clear spatio-temporal variations were observed in desert soil $\mathrm{CO}_{2}$ and $\mathrm{CH}_{4}$ fluxes, with significant differences in $\mathrm{C}$ emissions at different stages of vegetation recovery and BSCs development and in different seasons $(P<0.05)$. Furthermore, the dynamic $\mathrm{CO}_{2}$ flux patterns were consistent with soil temperature, exhibiting unimodal curves (Fig. 1). The average $\mathrm{CO}_{2}$ fluxes in the control, algal, lichen, and moss sites were 1.67, 2.61, 5.83, and $6.84 \mathrm{mmol} \mathrm{m}^{-2} \mathrm{~h}^{-1}$, respectively, during the growing season, and the average $\mathrm{CH}_{4}$ fluxes for the four sites were $-1.13,-1.67,-3.66$, and $-3.77 \mu \mathrm{mol} \mathrm{m}^{-2} \mathrm{~h}^{-1}$, respectively. The maximum $\mathrm{CO}_{2}$ flux in the control site was observed in early July, that for the algal site in late July, and those for the lichen and moss sites in early June. The minimum $\mathrm{CO}_{2}$ flux and $\mathrm{CH}_{4}$ absorption values for all four sample sites were observed in late October.

A two-way analysis of variance (ANOVA) (Table 2) showed that the effects of BSCs succession, sampling time, and their interaction on desert soil $\mathrm{CO}_{2}$ and $\mathrm{CH}_{4}$ fluxes were all highly significant $(\mathrm{P}<0.01)$, while the effects of BSC succession stages on soil $\mathrm{CO}_{2}$ and $\mathrm{CH}_{4}$ fluxes were greater than those of the sampling time. The soil temperature and water content were significantly affected by only sampling time $(\mathrm{P}<0.01)$ and not by BSCs succession stages or their interaction. This suggests that vegetation restoration and BSCs development could alter the $C$ flux patterns of desert soils but had little effect on soil hydrothermal redistribution.

\section{Effects of hydrothermal factors on $\mathrm{CO}_{2}$ and $\mathrm{CH}_{4}$ fluxes}

The correlation analysis (Fig. 2) showed that the soil $\mathrm{CO}_{2}$ fluxes of the four sites were all positively correlated with soil temperature $(P<0.05)$; the nonlinear model reflects the effect of temperature at different sites as follows: control $\left(F=2.391 \mathrm{~T}^{0.574}, R^{2}=0.869\right)$, algal $\left(F=1.454 \mathrm{~T}^{0.589}\right.$, $\left.R^{2}=0.831\right)$, lichen $\left(F=12.445 \ln (T)-37.597, R^{2}=0.763\right)$, and moss $\left(F=9.594 \ln (T)-25.083, R^{2}=0.517\right)$. The effect of soil water content on $\mathrm{CO}_{2}$ fluxes varied across different sites. With the development of BSCs, the influence of shallow soil water content on $\mathrm{CO}_{2}$ fluxes gradually increased. $\mathrm{CH}_{4}$ fluxes were not correlated with soil temperature at all sites and were positively correlated with soil water content only in the surface layer in algal and moss sites. The results indicate that soil temperature is the major factor controlling desert soil $\mathrm{CO}_{2}$ flux, although it does not influence $\mathrm{CH}_{4}$ absorption. In addition, vegetation restoration and BSCs development could alter the response patterns of $\mathrm{C}$ emissions to moisture conditions in desert soils.

\section{Variations of organic carbon density in desert soil}

SOC content and bulk density varied significantly among different succession stages of BSCs and soil depths $(P<0.05)$. In the $0-60 \mathrm{~cm}$ layer, SOC content gradually increased with BSCs succession and decreased with soil depth (Fig. 3). The range of SOC content for the control, algal, lichen, and moss sites was $0.18-0.41,0.22-0.73,0.44-1.96$, and $0.67-2.72 \mathrm{~g} \mathrm{~kg}^{-1}$, respectively. Among all sites, the moss site had the highest SOC content, which was $4.89,2.93$, and 1.28 times that of the control, algal, and lichen sites, respectively. Among the soil layers, the SOC content was the highest in the $0-10 \mathrm{~cm}$ soil layer, which was $3.85,2.62$,

Table 2 Effect of succession stages of biological soil crusts and sampling time on different soil parameters

\begin{tabular}{|c|c|c|c|c|c|c|}
\hline Item & Source of variation & $d f$ & Mean square & F-value & $P$-value & Partial $\eta^{2}$ \\
\hline \multirow[t]{3}{*}{ Soil $\mathrm{CO}_{2}$ fluxes } & Succession stages & 3 & 125.427 & 78.480 & $<0.001^{* *}$ & 0.797 \\
\hline & Time & 2 & 134.991 & 84.464 & $<0.001^{* *}$ & 0.738 \\
\hline & Succession stages $\times$ time & 6 & 20.057 & 12.550 & $0.004^{* *}$ & 0.557 \\
\hline \multirow[t]{3}{*}{ Soil $\mathrm{CH}_{4}$ fluxes } & Succession stages & 3 & 36.532 & 76.997 & $<0.001^{* *}$ & 0.794 \\
\hline & Time & 2 & 21.652 & 45.634 & $<0.001^{* *}$ & 0.603 \\
\hline & Succession stages $\times$ Time & 6 & 4.717 & 9.941 & $<0.001^{* *}$ & 0.499 \\
\hline \multirow[t]{3}{*}{ Soil temperature } & Succession stages & 3 & 18.722 & 0.746 & 0.529 & 0.036 \\
\hline & Time & 2 & 1138.474 & 45.389 & $<0.001^{* *}$ & 0.602 \\
\hline & Succession stages $\times$ time & 6 & 19.087 & 0.761 & 0.603 & 0.071 \\
\hline \multirow[t]{3}{*}{ Soil water content } & Succession stages & 3 & 2.994 & 1.152 & 0.335 & 0.054 \\
\hline & Time & 2 & 53.195 & 20.477 & $<0.001^{* *}$ & 0.406 \\
\hline & Succession stages $\times$ time & 6 & 1.191 & 0.459 & 0.836 & 0.044 \\
\hline
\end{tabular}

The effect of succession stages of BSCs, sampling time, and their interaction on soil $\mathrm{CO}_{2}$ and $\mathrm{CH}_{4}$ fluxes, temperature, and water content

*indicates significant correlation at $P<0.05$, and **indicates extremely significant correlation at $P<0.01$ 


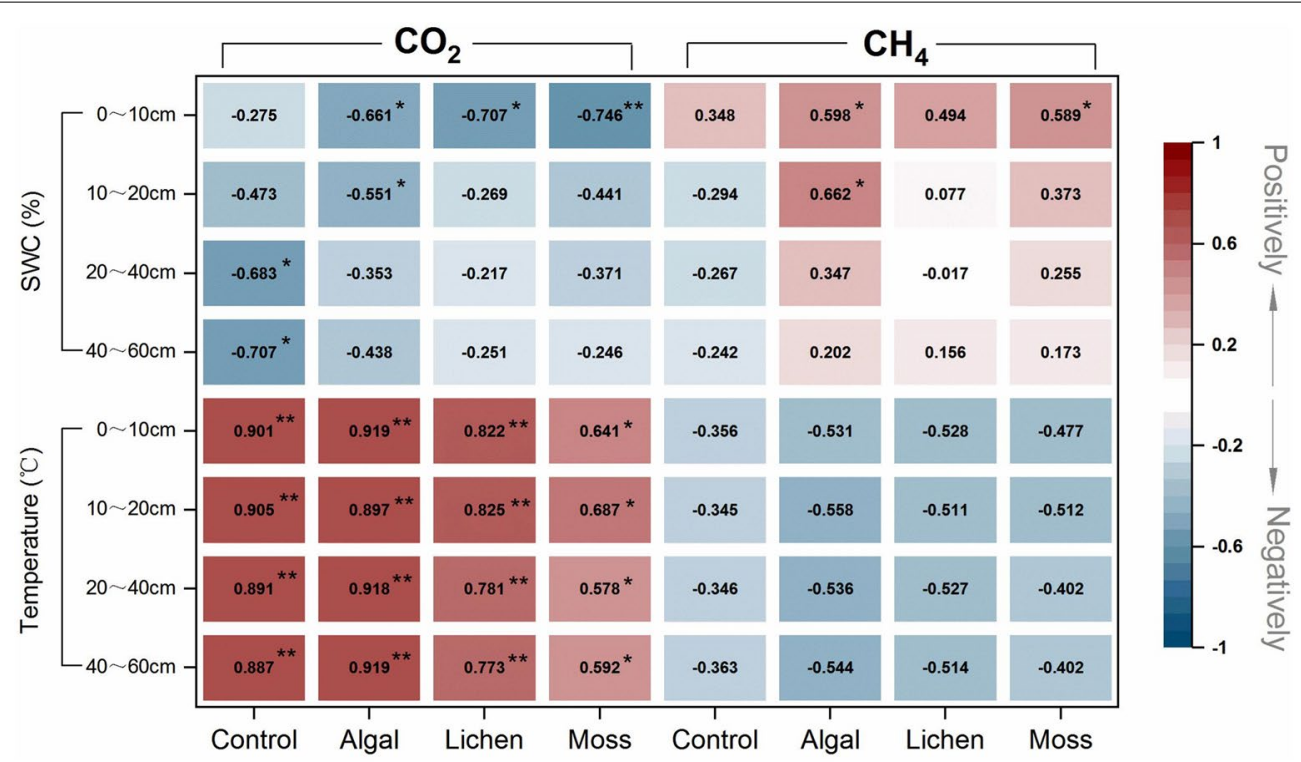

Fig. 2 Results of Pearson's correlation. Pearson's correlation coefficients between desert soil $\mathrm{CO}_{2}$ and $\mathrm{CH}_{4}$ fluxes and soil hydrothermal factors for different sites. Positive correlations are indicated in orange and negative correlations in brown
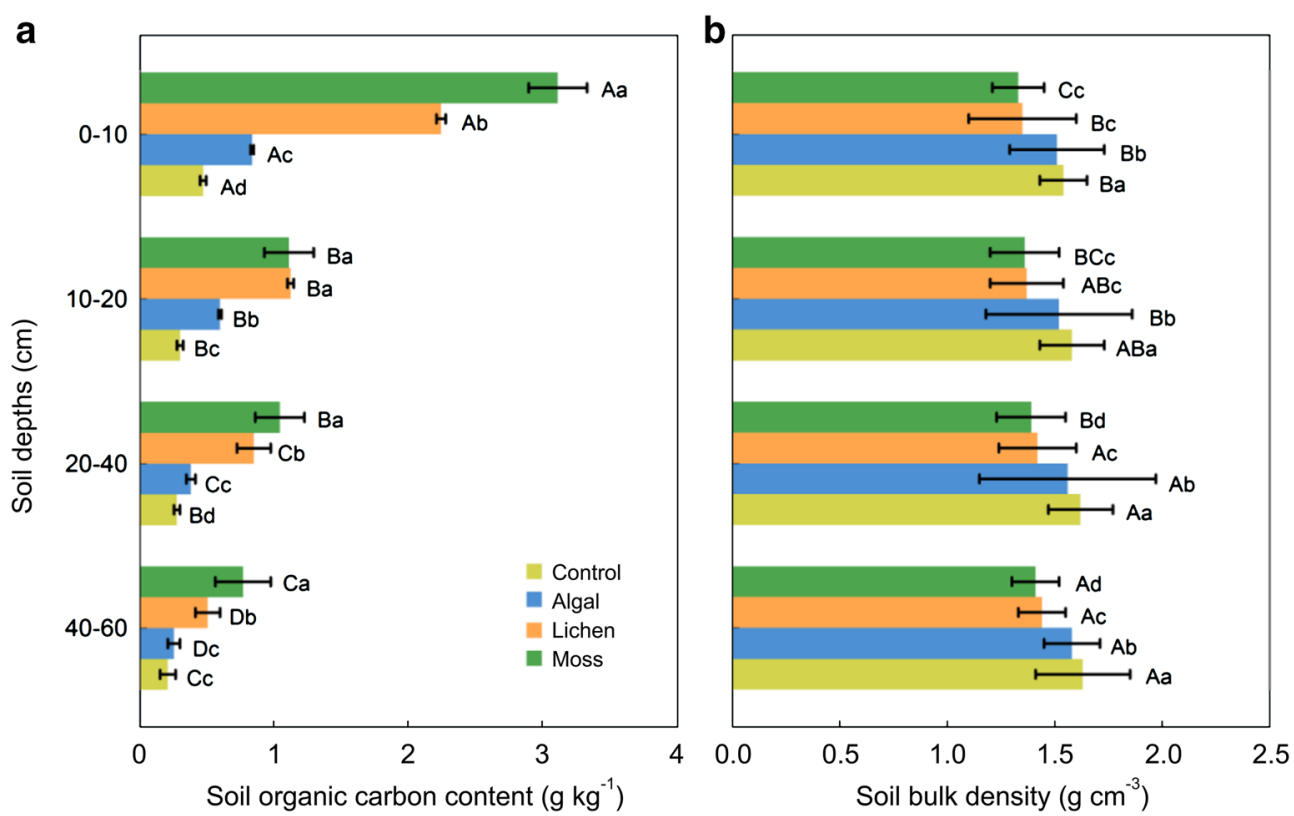

Fig. 3 Soil organic carbon (SOC) content and bulk density variation in sampling sites. Variation of soil organic carbon (SOC) content and bulk density at different sites. Different capital letters indicate significant differences at 0.05 level among different soil depths at the same site; the different small letters indicate significant differences at 0.05 level among the four sites at the same soil depth

and 2.12 times that in the $10-20,20-40$, and $40-60 \mathrm{~cm}$ soil layers, respectively. The spatial variation of soil bulk density was the opposite of SOC, gradually decreasing with BSCs succession and increasing with soil depth.
The total organic C (TOC) densities of desert soils at different stages of BSCs succession differed significantly $(P<0.05)$, which were $0.24,0.36,0.74$, and $0.94 \mathrm{~kg} \mathrm{~m}^{-2}$ for the control, algal, lichen, and moss sites, respectively, 
thus showing a significant increasing trend with BSCs succession (Fig. 4). With the exception of control, the TOC density of surface soil $(0-10 \mathrm{~cm})$ accounted for the

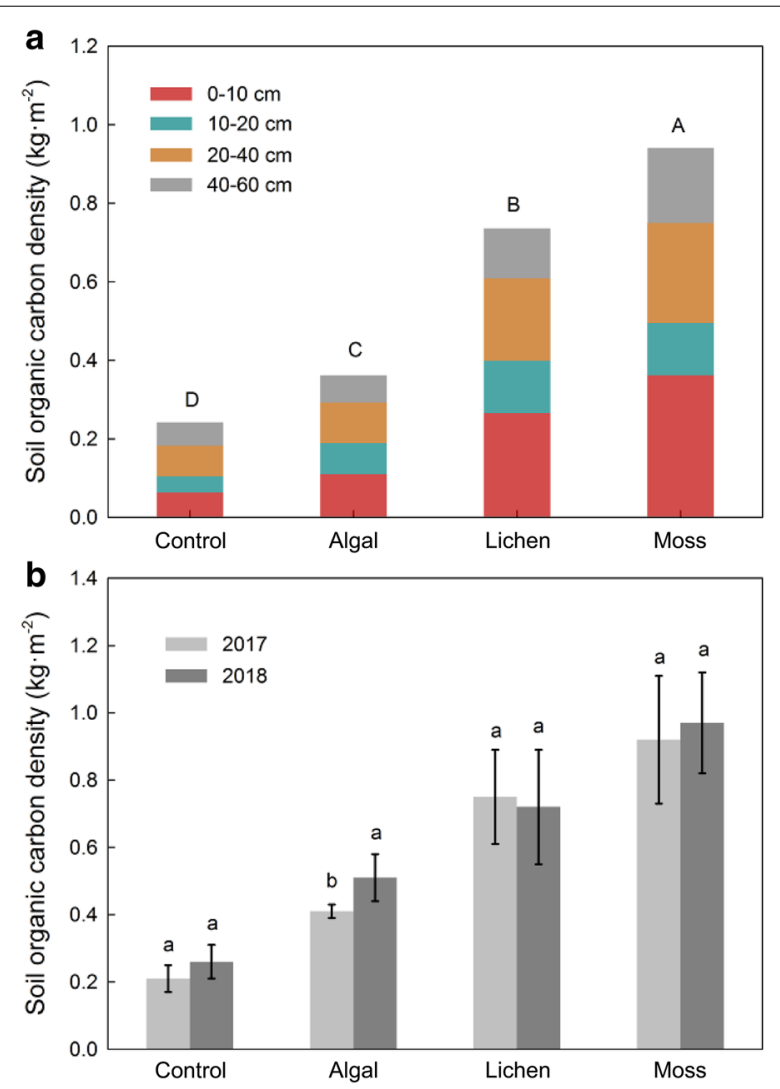

Fig. 4 Characteristics of soil organic carbon density. Characteristics of soil organic carbon (SOC) density in the control, algal, lichen, and moss sites. The top panel shows the variation characteristics of SOC density with soil depth, different capital letters indicate significant differences between plots. The bottom panel shows annual variation of SOC density, different small letters indicate significant differences from year to year. Data are shown as means with standard errors largest proportion of the soil profile in the other three sample sites, showing clear nutrient enrichment. The total SOC densities of the control, algal, and moss sites were all slightly higher in 2018 than in 2017, but the opposite was true for the lichen site.

The effects of BSCs succession and soil depth on SOC content, bulk density, and SOC density were all highly significant $(P<0.01)$, but their interaction only had significant effects on SOC content (Table 3). Moreover, the effect of BSCs succession on SOC density was greater than that of soil depth, indicating that vegetation restoration and BSCs development can significantly alter soil C stocks and promote soil C storage.

\section{Correlation between annual soil surface carbon fluxes and organic carbon density during the growing season} During the growing season, desert soil surface $C$ fluxes gradually increased with vegetation recovery and BSCs succession. The annual soil surface $\mathrm{C}$ fluxes for the control, algal, lichen, and moss sites were 316.50, 492.04, 1102.81 , and $1292.78 \mathrm{gC} \mathrm{m}^{-2}$ year $^{-1}$, respectively. The Pearson's correlation analysis (Table 4) showed that the annual surface $\mathrm{C}$ emission of desert soils undergoing vegetation recovery were significantly correlated with SOC density in the $0-10 \mathrm{~cm}$ and $10-20 \mathrm{~cm}$ layers $(P<0.05)$ as well as with that of the soil profile.

\section{Discussion}

\section{Seasonal variation of desert soil $\mathrm{CO}_{2}$ and $\mathrm{CH}_{4}$ fluxes and response to hydrothermal factors}

This study showed that clear seasonal variations could be observed in desert soil $\mathrm{CO}_{2}$ fluxes from the control, algal, lichen, and moss sites, all of which showed unimodal curves consistent with the soil temperature; however, there were no significant seasonal variation in $\mathrm{CH}_{4}$ flux, and the desert soils in all sites exhibited $\mathrm{CH}_{4}$ absorption. Furthermore, the correlation analysis

Table 3 Effects of succession stages on soil organic carbon (SOC) sequestration

\begin{tabular}{|c|c|c|c|c|c|c|}
\hline Item & Source of variation & $D f$ & Mean square & F-value & $P$-value & Partial $\eta^{2}$ \\
\hline \multirow[t]{3}{*}{ Soil organic carbon content } & Succession stages & 3 & 2.144 & 22.705 & $<0.001^{* *}$ & 0.831 \\
\hline & Soil depths & 3 & 2.084 & 22.062 & $<0.001^{* *}$ & 0.752 \\
\hline & Succession stages $\times$ soil depths & 9 & 0.306 & 3.240 & $0.019^{* *}$ & 0.714 \\
\hline \multirow[t]{3}{*}{ Soil bulk density } & Succession stages & 3 & 0.095 & 2023.000 & $<0.001^{* *}$ & 0.795 \\
\hline & Soil depths & 3 & 0.014 & 292.867 & $<0.001^{* *}$ & 0.774 \\
\hline & Succession stages $\times$ soil depths & 9 & $<0.001$ & 2.259 & 0.074 & 0.238 \\
\hline \multirow[t]{3}{*}{ Soil organic carbon density } & Succession stages & 3 & 0.063 & 16.349 & $<0.001^{* *}$ & 0.726 \\
\hline & Soil depths & 3 & 0.024 & 6.345 & $0.005^{* *}$ & 0.633 \\
\hline & Succession stages $\times$ soil depths & 9 & 0.006 & 1.618 & 0.192 & 0.089 \\
\hline
\end{tabular}

The effect of different succession stages of biological soil crusts (BSCs), soil depths, and their interaction on soil organic carbon SOC sequestration

*indicates significant correlation at $P<0.05$, and **indicates extremely significant correlation at $P<0.01$ 
Table 4 Pearson's correlation coefficients between desert soil surface C emissions and SOC density

\begin{tabular}{|c|c|c|c|c|c|c|}
\hline \multirow[t]{2}{*}{ Item } & \multirow{2}{*}{$\begin{array}{l}\text { Soil carbon } \\
\text { emissions }\end{array}$} & \multicolumn{5}{|c|}{ SOC density } \\
\hline & & $0-10 \mathrm{~cm}$ & $10-20 \mathrm{~cm}$ & $20-40 \mathrm{~cm}$ & $40-60 \mathrm{~cm}$ & $0-60 \mathrm{~cm}$ \\
\hline Soil carbon emissions & 1 & $0.951^{*}$ & $0.966^{*}$ & 0.845 & 0.813 & $0.911^{*}$ \\
\hline \multicolumn{7}{|c|}{ Soil organic carbon density } \\
\hline $0-10 \mathrm{~cm}$ & & 1 & 0.835 & $0.997^{* *}$ & $0.986^{*}$ & $0.892^{*}$ \\
\hline $10-20 \mathrm{~cm}$ & & & 1 & 0.848 & 0.866 & $0.905^{*}$ \\
\hline $20-40 \mathrm{~cm}$ & & & & 1 & $0.974^{*}$ & $0.932^{*}$ \\
\hline $40-60 \mathrm{~cm}$ & & & & & 1 & 0.816 \\
\hline $0-60 \mathrm{~cm}$ & & & & & & 1 \\
\hline
\end{tabular}

${ }^{*}$ indicates significant correlation at $P<0.05,{ }^{*}$ indicates extremely significant correlation at $P<0.01$

revealed a significant positive correlation only between $\mathrm{CO}_{2}$ fluxes and soil temperature, indicating that soil temperature is the main factor controlling $\mathrm{CO}_{2}$ fluxes in desert soils, although change in soil temperature could not affect $\mathrm{CH}_{4}$ absorption. Liu et al. also found in a study on Artemisia ordosica shrubland in the $\mathrm{Mu}$ Us Desert that soil heterotrophic and autotrophic respiration were mainly controlled by soil temperature [16]. Furthermore, other researchers drew the same conclusion in studies on semi-arid desert grasslands [17] and an arid desert in northwest China [18]. The direct effect of soil temperature on soil $\mathrm{CO}_{2}$ fluxes primarily stems from the sensitivity of the components of $\mathrm{C}$ fluxes to temperature changes. The soil $\mathrm{CO}_{2}$ fluxes measured in this study were in the form of total soil respiration, which included plant root and rhizosphere microbial respiration, soil microbial respiration, soil animal respiration, BSCs respiration, and mycorrhizal respiration. Soil temperature can change the community composition structure of soil microorganisms as well as the number of microbial communities, and an increase in temperature within a certain range can promote microbial proliferation [19]. Soil temperature can also significantly affect microbial activity, and as temperature increases, an increasing number of molecules reach or exceed their own activation energy, thus accelerating the reaction and increasing the $\mathrm{CO}_{2}$ efflux [20]. In addition, the existing root biomass of plants is extremely sensitive to soil temperature changes [21], while living roots can perform autotrophic respiration and dead roots are substrates for heterotrophic respiration. Therefore, an increase in root biomass accumulation with increasing soil temperature will inevitably lead to an increase in soil $\mathrm{CO}_{2}$ flux. The insensitivity of $\mathrm{CH}_{4}$ absorption to soil temperature was mainly due to the fact that methane-oxidizing bacteria are often mesophilic, relatively insensitive to temperature changes and able to maintain high activity over a wide range of temperature change [22].

The effect of soil water content on soil $\mathrm{CO}_{2}$ and $\mathrm{CH}_{4}$ fluxes in arid and semi-arid desert areas is relatively complex. In this study, the soil water content had a weak effect on soil $\mathrm{CO}_{2}$ and $\mathrm{CH}_{4}$ fluxes. During the growing season, the soil water content only showed negative correlations with soil $\mathrm{CO}_{2}$ fluxes and positive correlations with $\mathrm{CH}_{4}$ fluxes in the surface layer of the BSC fixed sands, which is consistent with the results of studies on soil C fluxes in desert Populus plantations [23] and Halostachys caspica communities [24]. This could be attributed to the fact that in desert areas where water is scarce, the plant canopy begins to experience water stress when soil water content is low, and the proportion of soluble carbohydrates allocated to the roots will increase, thus resulting in higher root respiration and increased soil $\mathrm{CO}_{2}$ efflux [25]. Contrary to the results of the present study, researchers have reported a significant positive correlation between soil C flux and water content in arid sand burial areas [26] and desert Haloxylon ammodendron forests [27], whereas $\mathrm{Li}$ et al. observed no correlation between the two [28]. This complicated situation may have arisen because it is only when soil water content reaches the wilting point of soil organisms (roots or microorganisms) or exceeds the field water holding capacity that it has a significant impact on soil $\mathrm{C}$ flux. If the change in moisture does not exceed the upper and lower bounds and is not sufficient to affect soil microbial or root viability, then it will be difficult to clearly measure the effect of moisture on soil C flux because, at this point, the effect of soil moisture can be easily masked by other factors [29]. 


\section{Changes in organic carbon content and density of desert soils during BSC succession}

In this study, the organic $C$ content and density of desert soils showed regular variations in both horizontal and vertical space. Using BSC succession as the horizontal axis, SOC content and density increased continuously during this process, with the former increasing by 4.89 times and the latter by 3.92 times as the succession progressed from the control to moss sites. This indicates that artificial planting to promote sand fixation can effectively increase the $\mathrm{C}$ storage capacity of desert soils, which is consistent with the results of studies on desertification reversal in the $\mathrm{Mu}$ Us Desert [30], the vegetation-based sand fixation zone in the Tengger Desert [31], and the vegetation restoration process in the Horqin Desert [32]. First, the succession of BSCs promoted the accumulation of organic carbon in the desert surface soil. The main components of BSCs are cryptogams, such as cyanobacteria, green algae, moss, lichens, etc. These plants can carry out photosynthesis, which is an important channel for $\mathrm{CO}_{2}$ to enter the ecosystems present in arid and semi-arid regions. Under suitable light, temperature, and water conditions, the photosynthetic carbon sequestration potential of BSCs mainly depends on their biological composition [33]. Studies have shown that BSCs at the later stages of development contain lichens or mosses and have higher photosynthetic rates than the algae crust, which is the early stage of succession. For example, in the Chihuahuan Desert, photosynthetic rates of BSCs in the later stages of development were 2.4-2.8 times higher than those in the early stage of succession [34]. Thus, the positive succession of BSCs will significantly increase the amount of $C$ entering the ecosystem through BSCs. Second, the synergistic and interactive vegetationsoil feedback relationship is the driving force behind the changes in soil properties. As the population and quantity of surface vegetation increases, the litter and root biomass will accumulate, and a large amount of organic residue will decompose and revert to soil, thus increasing its organic $C$ content [35]. Simultaneously, the surface microhabitat will change under the action of vegetation growth, creating favorable conditions for soil microbial colonization and BSC development. The former's death, decomposition, and metabolic secretions as well as the latter's formation of loose, stable humus through cryptogamic cementation, are also direct sources of SOC [36]. Moreover, surface coverage by herbage, shrubs, and BSC can effectively attenuate the activity of mobile dunes and thus reduce the loss of soil $\mathrm{C}$ pool due to wind erosion. Using the vertical changes in soil depth as the axis, we found that the organic $\mathrm{C}$ content and density of artificially fixed sands decreased with increasing depth. The $\mathrm{C}$ content of the surface soil $(0-10 \mathrm{~cm})$ was 3.84 times that of deep soil $(40-60 \mathrm{~cm})$, thus exhibiting marked nutrient surface accumulation. Veldkamp et al. also showed that the $0-30 \mathrm{~cm}$ layer of desert soil accounted for $3.84 \%$ of the soil $\mathrm{C}$ stock in their study area, which demonstrated significant surface $C$ enrichment of desert soils [8]. This was due to the fact that plant-soil interactions mainly occur at the rhizosphere, and the rhizospheric effect of plants not only provides root $C$ input to the soil, but can also improve soil texture, especially the stability of soil aggregates, thus protecting the existing organic $\mathrm{C}$ in the soil [37]. In our study area, approximately $70 \%$ of the root biomass of S. cheilophila and A. ordosica shrubs was concentrated in the $0-30 \mathrm{~cm}$ soil layer, and hence the surface soil was inevitably the primary site for nutrient uptake and exudate secretion by the roots to modify soil texture [38]. Atmospheric dust fall and the input of organic residues all occur in the surface and shallow rhizospheric environments, where SOC is mainly accumulated. The study area is located in the semi-arid zone, where precipitation is scarce, water infiltration is difficult, and leaching action is weak. These factors have given rise to difficulties in shifting exogenous organic $\mathrm{C}$ to the deep soil, thereby forming a vertical pattern from nutrient-rich to nutrient-poor.

\section{Synergistic relationship between desert soil surface carbon emission and organic carbon sequestration}

In this study, the annual $\mathrm{C}$ flux at the soil surface increased by 4.08 times from the control to moss sites during the growing season, which was consistent with the analysis performed by Gao et al. [39]. The results showed that the annual soil surface $\mathrm{C}$ emissions were positively correlated with SOC density in the 0-10 and 10-20 cm layers. Fan et al. also found that the increase in soil $\mathrm{C}$ input was a major contributor to the increase in soil $\mathrm{C}$ emissions with the process of vegetation succession [40]. This is mainly because a large component of soil $\mathrm{CO}_{2}$ flux is produced by the heterotrophic respiration of microorganisms, and the number of microorganisms determines the level of flux [41]. In this study, the number of microorganisms in the soil under the BSC cover showed a clear trend of significant increase with BSC development (Fig. 5), and this increase was mainly dependent on the continuous supply of soil substrate. SOC is the main C source required for microbial proliferation, and its availability and content can directly affect the quantity and activity of microbial communities. In addition, with the involvement of soil microorganisms or animals, SOC is continuously decomposed and transformed into inorganic $\mathrm{C}$ and released as $\mathrm{CO}_{2}$ [42]. Moreover, although the desert soil exhibited net absorption of $\mathrm{CH}_{4}$ throughout the growing season, the amount of $\mathrm{CH}_{4}$ absorbed was very low, and the offset effect on $\mathrm{C}$ emissions was not 


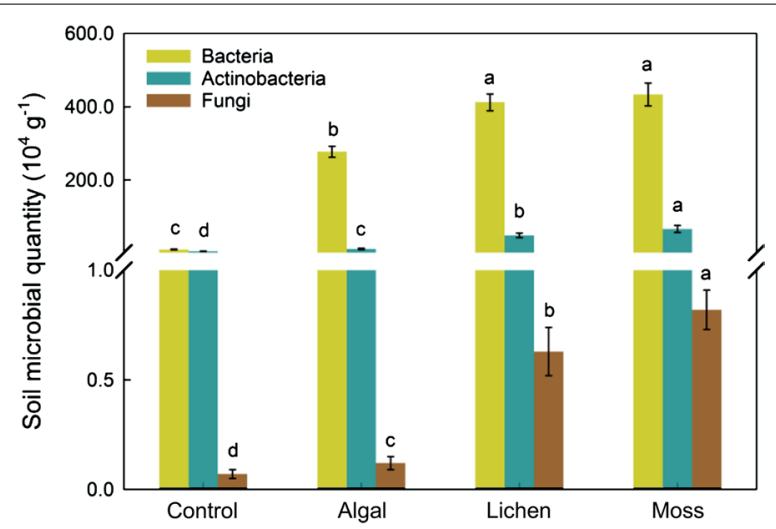

Fig. 5 Characteristics of soil microorganisms across sampling sites. Quantitative characteristics of soil microorganisms in the control, algal, lichen, and moss sites. Different letters indicate significant differences between plots. Data are shown as means with standard errors

significant. In semi-arid desert areas, artificial vegetation construction can promote rapid restoration of vegetation and the succession of BSCs. During this process, both vegetation and soil can absorb and fix a large amount of $\mathrm{C}$. Although the rate of soil respiration will increase, sand-binding area will act as a huge $C$ sink.

\section{Conclusion}

Following artificial sand fixation by vegetation in a semiarid desert, the changes in microhabitats gave rise to the formation and succession of BSCs, which led to significant changes in soil $\mathrm{C}$ emission patterns. During the growing season, vegetation restoration and BSCs succession can effectively increase $\mathrm{CO}_{2}$ emission and the $\mathrm{CH}_{4}$ absorption. Furthermore, $\mathrm{CO}_{2}$ fluxes were characterized by distinct seasonal dynamics, which was not the case with regard to $\mathrm{CH}_{4}$. Soil temperature was observed to be the major factor controlling $\mathrm{CO}_{2}$ flux; however, it did not influence $\mathrm{CH}_{4}$ absorption in desert soils, and soil water content had a weak effect on both $\mathrm{CO}_{2}$ and $\mathrm{CH}_{4}$ fluxes. During vegetation restoration and BSCs succession, the organic $\mathrm{C}$ content and TOC density of desert soils gradually increased, with clear signs of surface accumulation. The annual soil surface $\mathrm{C}$ emissions also showed an increasing trend, which was positively correlated with SOC density. The results of the present study illustrate that vegetation restoration and BSCs succession could increase soil $\mathrm{C}$ sequestration in desert soil.

\section{Materials and methods Study area profile}

The study area was located in Jungar Banner of Ordos City, Inner Mongolia Autonomous Region, which is a typical desert geomorphological type of eastern Hobq Desert. The study area has a temperate continental climate, characterized by a clear concurrence of precipitation and high temperatures. Its springs and winters are dry and windy, while its summers and autumns are hot with concentrated precipitation. The average annual temperature is $6.1-7.1{ }^{\circ} \mathrm{C}$, the average annual precipitation is $240-360 \mathrm{~mm}$, the average annual evaporation is $2560 \mathrm{~mm}$, the average annual sunshine duration is $3138 \mathrm{~h}$, the average annual frost-free period is 130-140 days, and the average annual wind speed is $3.3 \mathrm{~m} \mathrm{~s}^{-1}$. The soil in the study area was mainly aeolian sandy soil, comprising $2.61 \%$ clay and silt $(<0.05 \mathrm{~mm}), 3.92 \%$ ultrafine sand $(0.05-0.1 \mathrm{~mm})$, and $92.94 \%$ sand $(0.1-1 \mathrm{~mm})$. The main plant species included Salix cheilophila, Caragana korshinskii, Hedysarum mongolicum, Artemisia ordosica, Salsola collina, Psammochloa villosa, and Agriophyllum squarrosum. After the artificial fixation of sand in the study area, BSCs succession occurred gradually; algae, lichen, and moss crusts constitute the entire BSCs succession sequence.

\section{Sample sites}

The sample sites in the eastern Hobq Desert were divided according to the degree of vegetation restoration and the characteristics of BSCs development into the following types: (1) Algal crust-fixed sand (algal), where $S$. cheilophila cuttings were placed in a grid-like pattern in semi-mobile dunes to form a live biological sand barrier, improve the surface vegetation cover, and promote sand fixation; the vegetation restoration period was 8 years, and black mottled algal crusts had formed on the surface (chlorophyll a content: $0.31 \mu \mathrm{g} \mathrm{g}^{-1}$; scytonemin content: $0.28 \mu \mathrm{g} \mathrm{g}^{-1}$ ); (2) Lichen crust-fixed sand (lichen), which was afforested with $S$. cheilophila cuttings in bands to form stable $S$. cheilophila communities after pruning; the vegetation restoration period was 18 years, and dark brown patchy lichen crusts had formed on the surface (chlorophyll a content: $0.95 \mu \mathrm{g} \mathrm{g}^{-1}$; scytonemin content: $1.72 \mu \mathrm{g} \mathrm{g}^{-1}$ ); (3) Moss crust-fixed sand (moss), which was initially afforested with $S$. cheilophila cuttings in bands that eventually formed clusters of "S. cheilophila islands" with relatively large crowns through natural succession and had a large number of $A$. ordosica growing in the inter-island open space; the vegetation restoration period was 26 years, and the vegetation coverage was extensive, litter layer was thick, and continuous grayish-green moss crust had formed (chlorophyll a content: $1.93 \mu \mathrm{g} \mathrm{g}^{-1}$; scytonemin content: $7.62 \mu \mathrm{g} \mathrm{g}^{-1}$ ); (4) Control sample sites (control), which were bare mobile dunes with virtually no vegetation cover, only a few annual herbaceous plants, and strong wind erosion. The basic conditions of the sample sites are listed in Table 5. 
Table 5 Conditions of different sample sites

\begin{tabular}{|c|c|c|c|c|c|c|c|c|}
\hline Site & Location & Altitude (m) & $\begin{array}{l}\text { Vegetation } \\
\text { coverage } \\
(\%)\end{array}$ & $\begin{array}{l}\text { Dominant } \\
\text { species }\end{array}$ & $\begin{array}{l}\text { BSCs thickness } \\
(\mathrm{mm})\end{array}$ & $\begin{array}{l}\text { BSCs coverage } \\
(\%)\end{array}$ & $\begin{array}{l}\text { Herbage } \\
\text { density } \\
\text { (plants } \mathrm{m}^{-2} \text { ) }\end{array}$ & $\begin{array}{l}\text { Shrub density } \\
\text { (plants } \cdot \mathrm{hm}^{-2} \text { ) }\end{array}$ \\
\hline Control & $\begin{array}{l}110^{\circ} 46^{\prime} 33.378^{\prime \prime} \mathrm{E}_{1} \\
40^{\circ} 04^{\prime} 49.183^{\prime \prime} \mathrm{N}\end{array}$ & 1198 & $2.65 \pm 0.18$ & $\begin{array}{l}\text { Psammochloa vil- } \\
\text { losa + Agriophyl- } \\
\text { lum squarrosum }\end{array}$ & 0 & 0 & $15 \pm 3$ & 0 \\
\hline Algal & $\begin{array}{l}110^{\circ} 47^{\prime} 29.805^{\prime \prime} \mathrm{E} \\
40^{\circ} 04^{\prime} 34.179^{\prime \prime} \mathrm{N}\end{array}$ & 1115 & $38.63 \pm 2.74$ & $\begin{array}{l}\text { Salix psammoph- } \\
\text { ila+ Hedysarum } \\
\text { mongolicum }\end{array}$ & $1.18 \pm 0.06$ & $11.31 \pm 1.22$ & $54 \pm 6$ & $121 \pm 4$ \\
\hline Lichen & $\begin{array}{l}110^{\circ} 46^{\prime} 56.978^{\prime \prime} \mathrm{E}_{1} \\
40^{\circ} 04^{\prime} 40.868^{\prime \prime} \mathrm{N}\end{array}$ & 1147 & $55.32 \pm 4.33$ & $\begin{array}{l}\text { Salix psammoph- } \\
\text { ila+Caragana } \\
\text { korshinskii }\end{array}$ & $8.84 \pm 1.63$ & $24.66 \pm 5.42$ & $134 \pm 21$ & $174 \pm 7$ \\
\hline Moss & $\begin{array}{l}110^{\circ} 46^{\prime} 28.344^{\prime \prime} \mathrm{E}_{1} \\
40^{\circ} 04^{\prime} 45.998^{\prime \prime} \mathrm{N}\end{array}$ & 1159 & $65.76 \pm 8.12$ & $\begin{array}{l}\text { Salix psammoph- } \\
\text { ila+Artemisia } \\
\text { ordosica }\end{array}$ & $13.66 \pm 3.14$ & $33.87 \pm 4.78$ & $177 \pm 32$ & $133 \pm 12$ \\
\hline
\end{tabular}

Control mobile dunes, Algal algal crust-fixed sand, Lichen lichen crust-fixed sand, Moss moss crust-fixed sand, BSCs biological soil crust

\section{Gas sample measurement}

Soil $\mathrm{CO}_{2}$ and $\mathrm{CH}_{4}$ gas samples were collected during the plant growth seasons (May-October) in 2017 and 2018. At each sample site, three $2 \mathrm{~m} \times 2 \mathrm{~m}$ gas sampling plots were selected on a relatively flat terrain, and all herbage within the plots was removed to ensure BSCs integrity as much as possible. $\mathrm{CO}_{2}$ and $\mathrm{CH}_{4}$ collections were performed in a closed static chamber consisting of a cylindrical top chamber (diameter: $320 \mathrm{~mm}$; height: $600 \mathrm{~mm}$ ) and a base. The top wall of the chamber was equipped with a fan to ensure even mixing of gases in the chamber, and the base was embedded in the soil to a depth of $15 \mathrm{~cm}$. The top chamber was fastened to the base, 2 min prior to each sampling session, and water was injected into the grooves of the base to seal it in order to prevent gas exchange between the inside and outside of the chamber during the sampling process. Sampling was conducted three times per month with intervals of $\sim 10$ days at all four sample sites. Each sampling time was fixed at 09:00-12:00 am to reduce systematic errors. Timing began when the top chamber was fastened to the base, and gas samples were collected in triplicate $(50 \mathrm{~mL}$ per sampling bag) at 0,15 , and $30 \mathrm{~min}$. The sampling tool was a medical syringe with a three-way valve, and the gas samples were stored in aluminum foil gas sampling bags.

The gas samples were brought back to the laboratory and stored at a low temperature $\left(-4^{\circ} \mathrm{C}\right)$. The $\mathrm{CO}_{2}$ and $\mathrm{CH}_{4}$ concentration in the gas samples were measured using a gas chromatograph (Agilent 4890D, USA), and the measurement was completed within 7 days.

\section{Measurement of soil hydrothermal factors}

The meteorological data of the study area were recorded by a small automatic weather station (HOBO, USA). Soil hydrothermal factors were measured dynamically in parallel with gas sampling, involving the stratified measurement of soil temperature and water content at different soil depths of $0-10 \mathrm{~cm}, 10-20 \mathrm{~cm}, 20-40 \mathrm{~cm}$, and 40-60 cm using a rapid moisture meter (TRIME PICO, Germany).

\section{Measurement of SOC and microorganisms}

Two soil surveys were conducted at the sample sites in August 2017 and August 2018. Three soil profiles were randomly excavated within each sample site, and after determining the soil horizons, $200 \mathrm{~g}$ of mixed samples were obtained at the profile depths of $0-10,10-20$, 20-40, and 40-60 cm, packed into non-woven bags, and brought back to the laboratory. After removing plant roots and gravel, the samples were air-dried naturally, and the organic $\mathrm{C}$ content was determined by potassium dichromate-concentrated sulfuric acid oxidation subjected to external heating. The soil bulk density was measured using the volumetric ring method. The volume of the ring was $100 \mathrm{~cm}^{3}$, and the determination was repeated three times for each layer. To determine the quantity of soil microbial communities, only soil samples collected from the surface soil $(0-10 \mathrm{~cm})$ under crust cover were used, and the number of soil bacteria, actinomycetes, and fungal strains was determined using a quantitative fluorescence polymerase chain reaction assay. UltraClean DNA Isolation Kit (Mo Bio Laboratories, Solana Beach, CA, USA) was used to extract total microbial DNA, a C1000TM Touch Thermal PCR instrument was used for DNA amplification, and the number of microbial strains present in each sample was determined by Fluorescence Ration PCR (Bio-Rad). 


\section{Data processing}

Soil $\mathrm{CO}_{2}$ and $\mathrm{CH}_{4}$ flux was calculated as the amount of gas exchange per unit area of soil based on the changes in gas concentration over time, using the following equation:

$$
F=\rho \cdot h \cdot \frac{d C}{d t} \cdot \frac{273}{273+T}
$$

where $F$ is the measured gas flux $\left(\mathrm{CO}_{2}\right.$ unit $\mathrm{mmol} \mathrm{m}^{2} \mathrm{~h}^{-1}$; $\mathrm{CH}_{4}$ unit $\left.\mu \mathrm{mol} \mathrm{m} \mathrm{m}^{2} \mathrm{~h}^{-1}\right), \rho$ is the gas density $\left(\mathrm{kg} \mathrm{m}^{-3}\right)$ under standard conditions, $h$ is the static closed chamber height $(\mathrm{m}), d C / d t$ is the slope of the gas concentration change inside the chamber, and $T$ is the average temperature $\left({ }^{\circ} \mathrm{C}\right)$ inside the chamber at the time of sampling.

The annual soil surface $\mathrm{C}$ flux $\left(\mathrm{gC} \mathrm{m}^{-2}\right.$ year $\left.^{-1}\right)$ during the growing season was calculated using the cumulative method, i.e., the cumulative flux was calculated by multiplying the average measured soil $\mathrm{CO}_{2}$ and $\mathrm{CH}_{4}$ flux for each month by the number of days in the month as the step size. $\mathrm{CH}_{4}$ emissions were converted into $\mathrm{CO}_{2}$ emissions equivalents using a factor of 28 [43].

SOC density is the amount of SOC stored per unit area at a given soil depth. The organic $\mathrm{C}$ density in layer $i$ of the soil profile was calculated using the following equation:

$$
S O C_{i}=C_{i} \times D_{i} \times H_{i} \times\left(1-G_{i}\right) / 100,
$$

where $S O C_{i}$ is the organic $\mathrm{C}$ density of layer $i\left(\mathrm{~kg} \cdot \mathrm{m}^{-2}\right), C_{i}$ is the organic C content of layer $i\left(\mathrm{~g} \cdot \mathrm{kg}^{-1}\right), D_{i}$ is the bulk density of layer $i\left(\mathrm{~g} \cdot \mathrm{cm}^{-3}\right), H_{i}$ is the thickness of layer $i$ $(\mathrm{cm})$, and $G_{i}$ is the gravel volume content of layer $i(\%)$. The TOC density of the soil profile was obtained by summing up the organic $C$ density of each soil layer.

Data processing and graph plotting were performed using Excel and SigmaPlot 14.0, respectively, and statistical analyses were performed using SPSS 20.0. The least significant difference method was used to test the significance of differences in soil $\mathrm{CO}_{2}$ and $\mathrm{CH}_{4}$ flux, hydrothermal factors, SOC density, and other indicators among different sample sites $(\alpha=0.05)$. ANOVA and Pearson's test were used to analyze the correlation between the variables. The data in the tables and figures are presented as mean \pm standard error.

\section{Abbreviations \\ ANOVA: Analysis of variance; BSC: Biological soil crust; SOC: Soil organic car- bon; TOC: Total organic carbon.}

\section{Acknowledgements}

We would like to thank Editage (www.editage.cn) for their help with editing the manuscript.

\section{Authors' contributions}

All authors were involved in performing the experiments. BW wrote the manuscript, $J \mathrm{~L}$ revised the manuscript, and XZ and CW processed the data and prepared the figures. All authors read and approved the final manuscript.

\section{Funding}

This work was funded by the Inner Mongolia Science and Technology Project (Grant Number 201802107) and the Inner Mongolia Natural Science Foundation (Grant Number 2018MS05004).

\section{Availability of data and materials}

The datasets generated during and/or analyzed during the current study are available from the corresponding author on reasonable request.

\section{Declarations}

\section{Competing interests}

The authors declare that there are no competing interests.

\section{Author details}

${ }^{1}$ College of Desert Control Science and Engineering, Inner Mongolia Agricultural University, Hohhot 010018 , China. ${ }^{2}$ Inner Mongolia Academy of Forestry Sciences, Hohhot 010010, China. ${ }^{3}$ Institute of Water Resource for Pasturing Area, Ministry of Water Resources, Hohhot 010019, China.

Received: 18 February 2021 Accepted: 6 September 2021

Published online: 13 September 2021

\section{References}

1. Raich JW, Potter CS. Global patterns of carbon dioxide emissions from soils. Global Biogeochem Cycles. 1995;9(1):23-36. https://doi.org/10. 1029/94GB02723.

2. Hamdi S, Chevallier T, Ben Aïssa N, Ben Hammouda M, Gallali T, Chotte JL, et al. Short-term temperature dependence of heterotrophic soil respiration after one-month of pre-incubation at different temperatures. Soil Biol Biochem. 2011;43(9):1752-8. https://doi.org/10.1016/j.soilbio.2010. 05.025.

3. Anderson OR. Soil respiration, climate change and the role of microbial communities. Protist. 2011;162(5):679-90. https://doi.org/10.1016/j.protis. 2011.04.001.

4. Batjes NH. Total carbon and nitrogen in the soils of the world. Eur I Soil Sci. 2014;65(1):10-21. https://doi.org/10.1111/ejss.12114_2.

5. Hu YL, Li JT, Zhao SY, Zeng DH. Soil respiration response to precipitation reduction in a grassland and a Mongolian pine plantation in semi-arid northeast China. J For Res. 2019;30(5):1925-34. https://doi.org/10.1007/ s11676-018-0733-3.

6. Mazza G, Agnelli AE, Cantiani P, Chiavetta U, Doukalianou F, Kitikidou K, et al. Short-term effects of thinning on soil $\mathrm{CO}_{2}, \mathrm{~N}_{2} \mathrm{O}$ and $\mathrm{CH}_{4}$ fluxes in Mediterranean forest ecosystems. Sci Total Environ. 2019;651(1):713-24. https://doi.org/10.1016/j.scitotenv.2018.09.241.

7. Sharma CM, Gairola S, Baduni NP, Ghildiyal SK, Suyal S. Variation in carbon stocks on different slope aspects in seven major forest types of temperature region of Garhwal Himalaya. India J Biosci. 2011;36(4):701-8. https:// doi.org/10.1007/s12038-011-9103-4.

8. Veldkamp E, Weita AM, Staritsky IG, Huising EJ. Deforestation trends in the Atlantic Zone of Costa Rica: a case study. Land Degrad Dev. 1992;3(2):7184. https://doi.org/10.1002/ldr.3400030202.

9. Poulter B, Frank D, Ciais P, Myneni RB, Andela N, Bi J, et al. Contribution of semiarid ecosystems to inter-annual variability of the global carbon cycle. Nature. 2014;509(7502):600-3. https://doi.org/10.1038/nature13376.

10. Zhang C, Lu DS, Chen X, Zhang YM, Maisupova B, Tao Y. The spatiotemporal patterns of vegetation coverage and biomass of the temperate deserts in central Asia and their relationships with climate controls. Remote Sens Environ. 2016;175:271-81. https://doi.org/10.1016/j.rse. 2016.01.002.

11. Cao $C Y$, Jiang DM, Teng $X H$, Jiang Y, Liang WJ, Cui ZB. Soil chemical and microbiological properties along a chronosequence of Caragana 
microphylla Lam. plantations in the Horqin sandy land of northeast China. Appl Soil Ecol. 2008;40(1):78-85. https://doi.org/10.1016/j.apsoil.2008.03. 008.

12. Castillo-Monroy AP, Maestre FT, Rey A, Soliveres S, García-Palacios P. Biological soil crust microsites are the main contributor to soil respiration in a semiarid ecosystem. Ecosystems. 2011;14(5):835-47. https://doi.org/ 10.1007/s10021-011-9449-3.

13. Chamizo S, Cantón Y, Miralles I, Domingo F. Biological soil crust development affects physicochemical characteristics of soil surface in semiarid ecosystems. Soil Biol Biochem. 2012;49:96-105. https://doi.org/10.1016/j. soilbio.2012.02.017.

14. Gao LQ, Zhao YG, Xu MX, Sun H, Yang QY. The effects of biological soil crust succession on soil ecological stoichiometry characteristics. Acta Ecol Sin. 2018:38:678-88.

15. Zhao Y, Li XR, Zhang ZS, Hu YG, Chen YL. Biological soil crusts influence carbon release responses following rainfall in a temperate desert, northern China. Ecol Res. 2014;29(5):889-96. https://doi.org/10.1007/ s11284-014-1177-7.

16. Liu P, Jia X, Yang Q, Zha TS, Wang B, Ma JY. Characterization of soil respiration in a shrubland ecosystem of Artemisia ordosica in Mu Us Desert. Sci Silvae Sin. 2018;54:10-7. https://doi.org/10.11707/j.1001-7488.20180502.

17. Nakano T, Nemoto M, Shinoda M. Environmental controls on photosynthetic production and ecosystem respiration in semi-arid grasslands of Mongolia. Agric For Meteorol. 2008;148(10):1456-66. https://doi.org/10. 1016/j.agrformet.2008.04.011.

18. Song WM, Chen SP, Wu B, Zhu YJ, Zhou YD, Li YH, et al. Vegetation cover and rain timing co-regulate the responses of soil $\mathrm{CO}_{2}$ efflux to rain increase in an arid desert ecosystem. Soil Biol Biochem. 2012;49:114-23. https://doi.org/10.1016/j.soilbio.2012.01.028.

19. Biasi C, Rusalimova O, Meyer H, Kaiser C, Wanek W, Barsukov P, et al. Temperature-dependent shift from labile to recalcitrant carbon sources of arctic heterotrophs. Rapid Commun Mass Spectrom. 2005;19(11):1401-8. https://doi.org/10.1002/rcm.1911.

20. Vose JM, Ryan MG. Seasonal respiration of foliage, fine roots, and woody tissues in relation to growth, tissue $\mathrm{N}$, and photosynthesis. Glob Change Biol. 2002;8(2):182-93. https://doi.org/10.1046/j.1365-2486.2002.00464.x.

21. Boone RD, Nadelhoffer KJ, Canary JD, Kaye JP. Roots exert a strong influence on the temperature sensitivity of soil respiration. Nature. 1998;396(6711):570-2. https://doi.org/10.1038/25119.

22. Raghoebarsing AA, Pol A, van de Pas-Schoonen KT, Smolders AJ, Ettwig KF, Rijpstra WI, et al. A microbial consortium couples anaerobic methane oxidation to denitrification. Nature. 2006:440(7086):918-21. https://doi. org/10.1038/nature04617.

23. Fu L, Zhang $Y Y$, Zhao WZ. Response of soil respiration to hydrothermal factors under different land cover types in a desert-oasis ecotone, northwest China. Pratacultural Sci. 2019;36:37-46.

24. Zhang LH, Chen YN, Li WH, Zhao RF, Ge HT. Soil respiration in desert ecosystems of the arid region. Acta Ecol Sin. 2008;28:1911-22.

25. Casals P, Romanyà J, Cortina J, Bottner P, Coûteaux MM, Vallejo VR. CO2 efflux from a Mediterranean semi-arid forest soil. I. Seasonality and effects of stoniness. Biogeochemistry. 2000;48(3):261-81. https://doi.org/10. 1023/A:1006289905991.

26. Teng JL, Jia RL, Hu YG, Xu BX, Chen MC, Zhao Y. Effects of sand burial on fluxes of greenhouse gases from the soil covered by biocrust in an arid desert region. Chin J Appl Ecol. 2016;27(3):723-34. https://doi.org/10. 13287/j.1001-9332.201603.018.

27. Wang $X Y, M a Q L$, Ji HJ. Soil respiration variation characteristics and its relationship with hydrothermic factor of artificial Haloxylon ammodendron forest in lower reaches of Shiyang River. Arid Land Geogr. 2019:42:570-80.

28. Li YT, Wang X, Wang ZM, Du ZY, Wang SG, Liu DX. Soil microorganism and soil respiration characteristics of Tamarix chinensis plantation of different ages in Yellow River Delta during the growing season. J Cent S Univ For Technol. 2019;39:86-92.

29. Chen QS, Li LH, Han XG, Yan ZD. Effects of water content on soil respiration and the mechanisms. Acta Ecol Sin. 2003;23:972-8.

30. Li C-P, Xiao C-W. Above- and belowground biomass of Artemisia ordosica communities in three contrasting habitats of the Mu Us Desert, northern China. J Arid Environ. 2007;70(2):195-207. https://doi.org/10.1016/j.jarid env.2006.12.017.

31. Chen YL, Zhang ZS, Zhao Y. Distribution of soil carbon in sand-binding area and its relation with soil properties. J Desert Res. 2017;37:296-304.

32. Li YQ, Zhao XY, Zhang FX, Awada T, Wang SK, Zhao HL, et al. Accumulation of soil organic carbon during natural restoration of desertified grassland in China's Horqin Sandy Land. J Arid Land. 2015;7(3):328-40. https://doi.org/10.1007/s40333-014-0045-1.

33. Marsh J, Nouvet S, Sanborn P, Coxson D. Composition and function of biological soil crust communities along topographic gradients in grasslands of central interior British Columbia (Chilcotin) and southwestern Yukon (Kluane). Can J Bot. 2006;84(5):717-36. https://doi.org/10.1109/TSP. 2007.914967.

34. Housman DC, Powers HH, Collins AD, Belnap J. Carbon and nitrogen fixation differ between successional stages of biological soil crusts in the Colorado Plateau and Chihuahuan Desert. J Arid Environ. 2006;66(4):62034. https://doi.org/10.1016/j.jaridenv.2005.11.014.

35. Von Lützow M, Kögel-Knabner I, Ekschmitt K, Flessa H, Guggenberger G, Matzner E, et al. SOM fractionation methods: relevance to functional pools and to stabilization mechanisms. Soil Biol Biochem. 2007;39(9):2183-207. https://doi.org/10.1016/j.soilbio.2007.03.007.

36. Feng Q, Endo KN, Guodong C. Soil carbon in desertified land in relation to site characteristics. Geoderma. 2002;106(1-2):21-43. https://doi.org/ 10.1016/S0016-7061(01)00099-4.

37. Wan QT, Xiao J, Ding JX, Zou TT, Zhang ZL, Liu Q, et al. Differences in root exudate inputs and rhizosphere effects on soil $\mathrm{N}$ transformation between deciduous and evergreen trees. Plant Soil. 2019;29:1-13. https://doi.org/ 10.1007/s11104-019-04156-0.

38. Jobbágy EG, Jackson RB. The vertical distribution of soil organic carbon and its relation to climate and vegetation. Ecol Appl. 2000;10(2):423-36. https://doi.org/10.1890/1051-0761(2000)010[0423:TVDOSO]2.0.CO;2.

39. Yanhong G, Lichao L, Rongliang J, Zhishan Z. Soil respiration patterns during restoration of vegetation in the Shapotou area, northern China. Acta Ecol Sin. 2012;32(8):2474-82. https://doi.org/10.5846/stxb200908011024.

40. Fan YX, Yang YS, Guo JF, Yang ZJ, Chen GS, Xie JS, et al. Changes in soil respiration and its temperature sensitivity at different successional stages of evergreen broadleaved forests in mid-subtropical China. Chin J Plant Ecol. 2014;38:1155-65.

41. Priess JA, de Koning GHJ, Veldkamp A. Assessment of interactions between land use change and carbon and nutrient fluxes in Ecuador. Agric Ecosyst Environ. 2001;85(1-3):269-79. https://doi.org/10.1016/ S0167-8809(01)00193-1.

42. Xu X, Zhou Y, Ruan HH, Luo YQ, Wang JS. Temperature sensitivity increases with soil organic carbon recalcitrance along an elevational gradient in the Wuyi Mountains. China Soil Biol Biochem. 2010;42(10):1811-5. https:// doi.org/10.1016/j.soilbio.2010.06.021.

43. IPCC. 2014: synthesis report. Contribution of working groups. Clim Change. 2014.

\section{Publisher's Note}

Springer Nature remains neutral with regard to jurisdictional claims in published maps and institutional affiliations. 